\title{
GLAND CELLS IN HYDRA: CELL CYCLE KINETICS AND DEVELOPMENT
}

\author{
TOBIAS SCHMIDT AND CHARLES N. DAVID \\ Zoologisches Institut der Universität, Luisenstr. 14, 8000 München 2, \\ Federal Republic of Germany
}

\section{SUMMARY}

The proliferative capacity of gland cells in Hydra attenuata was investigated. The results indicate that both gland cell proliferation and interstitial cell differentiation to gland cells contribute to the maintenance of the whole population. On the basis of $\left[{ }^{3} \mathrm{H}\right]$ thymidine incorporation and nuclear DNAA measurements, gland cells consist of at least three different populations. One population consists of rapidly proliferating cells with a cell cycle of about $72 \mathrm{~h}$. These cells are distributed throughout the body column. In the lower gastric region there is a population of non-cycling cells in $G_{2}$ while in the upper gastric region there is a population of noncycling cells in $G_{1}$. About half the $G_{1}$ population becomes a new antigen, SEC 1 , which is typical of mucus cells.

\section{INTRODUCTION}

Gland (zymogen) cells are interspersed singly between the more numerous and larger epithelial cells in the endoderm of Hydra. They are presumed to secrete proteolytic enzymes for the extracellular digestion of the prey (Beutler, 1924; Haynes \& Burnett, 1963). This cell type is club-shaped, tapering to a narrow base that extends towards the mesogloea and contains vacuoles or granules of different size and content (Rose \& Burnett, 1968). In many ways gland cells resemble the zymogen cells in the pancreas of vertebrates (Gauthier, 1963; Lentz, 1965). Secretion has been observed to be of the apocrine type: a portion of the granular part, mainly in the apical region of the cell, is pinched off into the gastric cavity after feeding. The basal portion of the cell then goes through resynthesis of the granules and another round of excretion (Bouillon, 1966; Kessler, 1975).

Gland cells exhibit a graded distribution along the body column of Hydra with a maximum density in the subhypostomal region. This cell type, which represents $25 \%$ of all endodermal cells, is scarce in the head of the animal and absent in the lower two-thirds of the peduncle and in the foot (Burnett, 1959; Campbell, 1967a; Bode et al. 1973).

More than one type of gland cell has been described (von Strelin, 1929; Semal van Gansen, 1954); these may, however, be different developmental stages of the same type (Hess, 1961). Rose \& Burnett (1968) described one type of zymogen cell with

Key words: Hydra, gland cell differentiation, cell cycle, proliferative capacity. 
granules of different sizes; the diameter of the granules increasing further down the body column.

From observations on the morphology of cells in histological sections gland cells have been reported as being derivatives of interstitial cells (Lentz, 1965). On the other hand gland cells in specified conditions have been observed to assume the appearance of interstitial cells (Burnett et al. 1966; Davis, 1973). This poses the question of whether they are an independent population or whether they are derived from another cell type, i.e. interstitial cells, by differentiation. In terms of the maintenance of gland cell populations, three major hypotheses have been proposed.

(1) Gland cells are proliferating cells and capable of self-renewal. This was suggested first by Tannreuther (1909), who observed mitotic figures in gland cells. Mitoses in gland cells were also observed by Burnett $(1959,1961)$, Diehl \& Burnett (1964) and Corff (1973), and by Campbell $(1965,1967 a)$, who found an even distribution of mitoses over the body axis. Additional support for the hypothesis that gland cells are autoreproductive came from Smid \& Tardent (1984), who found no interstitial to gland cell differentiation in recombination experiments between labelled ectoderm and unlabelled endoderm.

(2) Gland cells are interstitial cell products. McConnell (1931) observed mitotic figures not only in gland cells but also in the basal reserve cells, large interstitial cells in the endoderm of Hydra, and proposed that these cells were the precursors of gland cells in Hydra. This hypothesis was also favoured by several authors, mostly because of morphological similarities between these two cell types (e.g. see Burnett, 1959; Bouillon, 1966; Haynes \& Davis, 1969).

(3) Gland cells proliferate but require an interstitial cell input. On the basis of histological data, Kessler (1975) was able to follow the life-cycle of gland cells. Her data, as well as those of Bouillon (1966) and others (McConnell, 1929; Semal-Van Gansen, 1954; Rose \& Burnett, 1968), suggest that gland cells go through renewed cycles of cell division as well as synthesis and discharge of their vacuolar content. In addition she found interstitial cells migrating across the mesogloea and acquiring the morphology of gland cells. She concluded from these findings that interstitial cells differentiate into gland cells and that these then go through several rounds of division and synthesis of their vacuolar content and finally die. Further support for a role of the multipotent interstitial cell in gland cell replenishment comes from work by Marcum \& Campbell (1978), Fradkin et al. (1978) as well as Sugiyama \& Fujisawa (1978). When interstitial cells and consequently their derivatives are removed by different means, gland cells are often removed as well. Sometimes, however, they persist or decrease slowly with time (Marcum \& Campbell, 1978).

The question of the extent of self-renewal and whether the gland cells are capable of maintaining their own population is addressed in this paper. Gland cells are characterized with respect to their cell cycle parameters and proliferation rate. The results indicate that gland cells proliferate at a rate that is not sufficient for maintenance of the total population. A low rate of interstitial cell differentiation to gland cells occurs, however, and appears to be sufficient, together with gland cell proliferation, to maintain the gland cell population. 


\section{MATERIALS AND METHODS}

\section{Mass culture}

Hydra attenuata (Pall.) were used in all experiments. Cultures were maintained at $18^{\circ} \mathrm{C}$ in plastic trays with a volume of about 1 litre. The hydra used were large animals obtained by culture at a population density of about 1-2 hydra per ml. Hydra were fed freshly hatched Artemia nauplii once daily and the culture solution was exchanged after $6 \mathrm{~h}$ (Lenhoff $\&$ Brown, 1970).

\section{Maceration and cell determination}

For quantitatively preparing single cell suspensions from hydra tissue the maceration technique was used (David, 1973). Cell identification and quantification was also done according to David (1973). For the terminology of morphological regions in hydra we referred to Campbell \& Bode (1983).

\section{Pulse and continuous labelling of Hydra cells}

Hydra were labelled with $\left[\right.$ methyl $\left.{ }^{3} \mathrm{H}\right]$ thymidine $\left(30 \mathrm{Cimmol}^{-1}\right.$; Amersham, England). The compound was used at a concentration of either 25 or $50 \mu \mathrm{Ci} \mathrm{ml}^{-1}$ depending on the experiment. The label was administered by injecting about $0 \cdot 1-0.2 \mu \mathrm{l}$ into the gastric cavity of individual hydra using a 10- $\mu$ l Hamilton syringe fitted with a tip of finely drawn polyethylene tubing. Continuous labelling was achieved by repeated injections of radioactive thymidine at intervals of about $12 \mathrm{~h}$ (David \& Campbell, 1972). The cells were then spread on gelatin-coated microscope slides and dried overnight. For autoradiography the dried slides were washed briefly to remove excess maceration fluid and then covered with Kodak NTB-2 autoradiographic emulsion, exposed for 10 days at $4^{\circ} \mathrm{C}$ and developed. Autoradiographs were analysed using bright field and phase-contrast microscopy. The labelling index (labelled cells/total cells) was determined by counting at least 250 gland cells per sample. To minimize errors due to variability between animals $3-5$ hydra were used for each sample.

\section{Determination of the amount of DNA per nucleus}

In order to identify $G_{1}(2 n), S$ phase and $G_{2}(4 n)$ cells the relative amount of DNA per nucleus was determined microfluorometrically using the DNA-specific fluorochrome DAPI (Leeman \& Ruch, 1982). Macerated cells were spread on gelatin-coated microscope slides and after drying were stained with $0.5 \mu \mathrm{g} \mathrm{ml}^{-1}$ DAPI (4',6-diamidino-2-phenylindole dihydrochloride) for at least $2 \mathrm{~h}$ in McIlvain's buffer at $\mathrm{pH} 7$ (Coleman \& Maguire, 1982). The fluorescence intensity of single cell nuclei was measured photometrically with a Leitz MPS 40 photomultiplier attached to a Leitz Dialux 20 microscope fitted with a Leitz epifluorescence attachment and filterblock A (excitation wavelength $340-380 \mathrm{~nm}$; barrier filter $430 \mathrm{~nm}$ ). The diaphragm of the photomultiplier was always adjusted to the size of the nucleus. Hydra nerve cells served as a $2 n$ standard (David \& Gierer, 1974).

\section{The fractions of cells in the different cell cycle phases}

From the DNA measurements the fraction of cells in the different phases of the cell cycle was calculated according to Weijer et al. (1984) by fitting respective plots with theoretical curves. These were derived by summing a set of Gaussian distributions whose means corresponded to the DNA content of various cell cycle stages and whose areas were proportional to the number of cells in each particular stage. $G_{1}$ and $G_{2}$ were modelled as single Gaussian distributions; since the DNA content is not constant during $S$ phase, it was broken down into 8 subclasses and a Gaussian distribution constructed for each. All Gaussian distributions had the same coefficient of variation $(15 \%)$.

\section{Cell cycle analysis}

The cell cycle was calculated according to David (1983) and Bosch \& David (1984). For estimation of the length of $G_{1}$ and $G_{2}$ periods DNA measurements were done in conjunction with 
continuous labelling with $\left[{ }^{3} \mathrm{H}\right]$ thymidine. After labelling and subsequent maceration of the tissue the fluorescence intensity of gland cells was measured using the DAPI stain. These measured cells were mapped and after autoradiography checked for incorporation of label.

\section{Determination of the population doubling time}

Ten hydra each of about the same size were selected from the mass culture and grown separately in Petri dishes. They were fed regularly. Each day all animals from one dish were collected (including newly formed buds), macerated and the number of gland cells and epithelial cells were determined.

\section{Monoclonal antibody production}

The protocol used for generating monoclonal antibodies to Hydra cells is a modification of the procedure described by Oi \& Herzenberg (1980). Preparations of about $1.5 \times 10^{6}$ dissociated $\mathrm{Hydra}$ cells (Gierer et al. 1972) were suspended in $0.25 \mathrm{ml}$ phosphate-buffered saline-(PBS) including $100 \mu \mathrm{g}$ MDP (muramyldipeptide; Institut Pasteur, Paris, France) and injected into the peritoneum of a 8 - to 10 -week-old $\mathrm{Balb} / \mathrm{C}$ female mouse 24 days and 3 days before fusion. For fusion the mouse spleen was removed, dissociated, and cocentrifuged with the mouse myeloma P3 $\times 6 \mathrm{AG} 8563$ cells in the presence of polyethylene glycoll (PEG) (Galfre et al. 1977). After HAT selection, the hybridomas were screened by incubating culture supernatant on whole mounts of Hydra or on macerations of $H y d r a$ cells as described below. Hybridomas producing monoclonal antibodies to cells of interest, were cloned by limiting dilution and stored in liquid nitrogen.

Monoclonal antibody SEC 1 was produced against strain 105 of Hydra magnipapillata (Sugiyama \& Fujisawa, 1977). However, SEC 1 exhibits the same binding pattern in $H$. attenuata, so that experiments could be done with the latter species.

\section{Monoclonal antibody visualization}

Hybridomas were screened for the production of monoclonal antibodies that bound to specific cell types of Hydra using indirect immunofluorescence on macerates and on Lavdowsky's fixed whole hydra (whole mounts).

Whole mounts. Intact hydra were placed in a few drops of medium in a Petri dish. After relaxation the animals were fixed by flooding the Petri dish with Lavdowsky's fixative. After a fixation time of at least $5 \mathrm{~h}$ the animals were washed for half an hour in PBS with $0.1 \%$ bovine serum albumin (BSA) and placed in wells of a microtitre plate (Costar). They were incubated for $1 \mathrm{~h}$ in $50 \mu \mathrm{l}$ of culture supernatant followed by another $1 \mathrm{~h}$ incubation in a mixture of fluorescein isothyocyanate (FITC)-labelled goat anti-mouse immunoglobulin (Ig) G/IgM (Tago, Burlingame, $\mathrm{Ca})$, diluted 50 times in PBS containing $0.1 \%$ BSA and $0.1 \%$ azide. Whole mounts were placed on microscope slides, mounted in PBS/glycerol $(1: 9, \mathrm{v} / \mathrm{v})$ and observed with a Leitz Dialux 20 microscope equipped with an epifluorescence attachment and filterblock 12 (excitation wavelength $450-490 \mathrm{~nm}$; barrier filter $515 \mathrm{~nm}$ ).

Macerated cells. Preparations of macerated cells were spread on gelatin-coated slides and dried overnight. Cells were postfixed in $0.5 \%$ glutaraldehyde in PBS for $0.5 \mathrm{~h}$, washed in PBS for $0.5 \mathrm{~h}$ and incubated for $0.5 \mathrm{~h}$ in a $50 \mathrm{mM}$-phosphate buffer ( $\mathrm{pH} 7$ ) containing $20 \%$ foetal calf serum, $0.4 \mathrm{M}$-glycine and $0.1 \%$ Tween 80 . Slides were then covered with the primary antibody (culture supernatant) and placed in a humid chamber for $90 \mathrm{~min}$. Cells were incubated in FITC-labelled goat anti-mouse $\mathrm{IgG} / \mathrm{IgM}$ for $1 \mathrm{~h}$, washed $5 \mathrm{~min}$ in $\mathrm{PBS}$, then covered with $\mathrm{PBS} /$ glycerol (1:9) including $10 \mu \mathrm{g} \mathrm{ml}^{-1} p$-phenylenediamine (Johnson \& deNogueira Aranjo, 1981) (Sigma Chemicals Co.) to reduce bleaching and observed as above.

\section{DNA measurements in conjunction with antibody staining}

Macerates of hydra were postfixed for $0.5 \mathrm{~h}$ in $0.5 \%$ glutaraldehyde, rinsed briefly in PBS and incubated in DAPI for $2 \mathrm{~h}$ as described above. After a 5 min wash in PBS the slides were incubated in $20 \%$ foetal calf serum, $0.4 \mathrm{M}$-glycine, $0.1 \%$ Tween 80 in $50 \mathrm{~mm}$-phosphate buffer at $\mathrm{pH} 7$ and processed thereafter as described above for monoclonal antibody visualization, except that all incubations were done in the dark. Since DAPI and FITC have very different excitation and 
emission maxima, signals of the same cells could be monitored without interference by switching from filterblock $\mathrm{A}$ to $\mathrm{I} 2$.

\section{Grafting procedure}

Axial grafts were produced by stringing proximal halves of Evans Blue-stained and $\left[{ }^{3} \mathrm{H}\right]$ thymidine-labelled hydra as well as distal untreated halves onto a nylon fishline (Rubin \& Bode, 1982). Sleeves of polyethylene tubing were then strung onto both ends of the fishline to maintain the cut surfaces in close contact. After $1-2 \mathrm{~h}$ the grafts were taken off the fishline. The grafts were fed daily until use.

\section{Nitrogen mustard treatment}

Hydra were treated for $10 \mathrm{~min}$ with $0.01 \%$ freshly prepared nitrogen mustard (2,2-dichloro- $N$ methyldiethylamine $\cdot \mathrm{HCl}$; Sigma Chemical Co.) (Diehl \& Burnett, 1964). To stop the treatment, hydra were washed four times with culture medium. Since feeding accelerates the progressive elimination of interstitial cells from tissue hydra were fed daily until regeneration was initiated at day 4 by cutting off the distal half of the animal. At this time less than $2 \%$ of the original interstitial cell complement was present in such animals.

\section{RESULTS}

\section{Proliferative fraction of the gland cell population}

Pulse and continuous labelling experiments with $\left[{ }^{3} \mathrm{H}\right]$ thymidine yield extensive information about cell proliferation. Figs 1 and 2 show that gland cells are labelled at the time of administration of the $\left[{ }^{3} \mathrm{H}\right]$ thymidine pulse; therefore the gland cell population includes proliferating cells. About $70 \%$ of the cells become labelled in approximately $65 \mathrm{~h}$ (Fig. 1). Labelling the remaining $30 \%$ of the population takes about $200 \mathrm{~h}$. Therefore, there appear to be two different gland cell populations: one rapidly cycling population and a 'slow' population, which either has a prolonged cell cycle or no longer participates in proliferation.

The continuous labelling data are also compared with those of epithelial cells (Fig. 1A), which show a higher initial rate of labelling. In contrast to gland cells, $100 \%$ labelled cells are found after about $100 \mathrm{~h}$.

In order to see whether there are regional differences in gland cell proliferation, the labelling indices were determined separately in upper and lower gastric regions. Fig. 1B shows that the labelling index for the lower gastric region is about 5-10\% below that of the upper gastric region. Thus, the cells in the lower gastric region have a longer cell cycle or a larger fraction no longer participates in the cell cycle. A drop in the rate of labelling was observed at about the same time in both regions, i.e. at $65 \mathrm{~h}$.

The pulse labelling data (Fig. 2) show a trend toward higher labelling indices with time. Although the data points are scattered, there appears to be little or no change in the labelling index for the first $20-30 \mathrm{~h}$ but thereafter the labelling index increases steadily. The increase is about $6 \%$ per day and is due, at least partially, to differentiation of gland cells from interstitial cells (see Table 1 and Discussion).

\section{Characterization of the nuclear DNA content of gland cells}

The nuclear DNA content of gland cells was determined using the DNA-specific fluorochrome DAPI (Leeman \& Ruch, 1982). Fig. 3A shows the distribution of 
nuclear DNA content of gland cells in the gastric region. From these data the fraction of cells in the different phases of the cell cycle was calculated as described in Materials and Methods. About $68 \%$ of all cells have a DNA content of $4 n$ and are thus in the $G_{2}$ period of the cell cycle: $17 \%$ are in the $S$ phase; $15 \%$ of all gland cells have a DNA content similar to nerve cells $(2 n)$ and are thus in the $G_{1}$ phase of the cell cycle. The presence of such a substantial number in $2 n$ cells of the gland cell population is unusual since other proliferating cell types in Hydra do not have a detectable $G_{1}$ phase (Campbell \& David, 1974).

Fig. 3B-E shows the nuclear DNA content of gland cells in different parts of the gastric region and in the hypostome. Differences in the distribution of $2 n$ gland cells are obvious (Fig. 3B-E). This population is almost completely absent in the lower
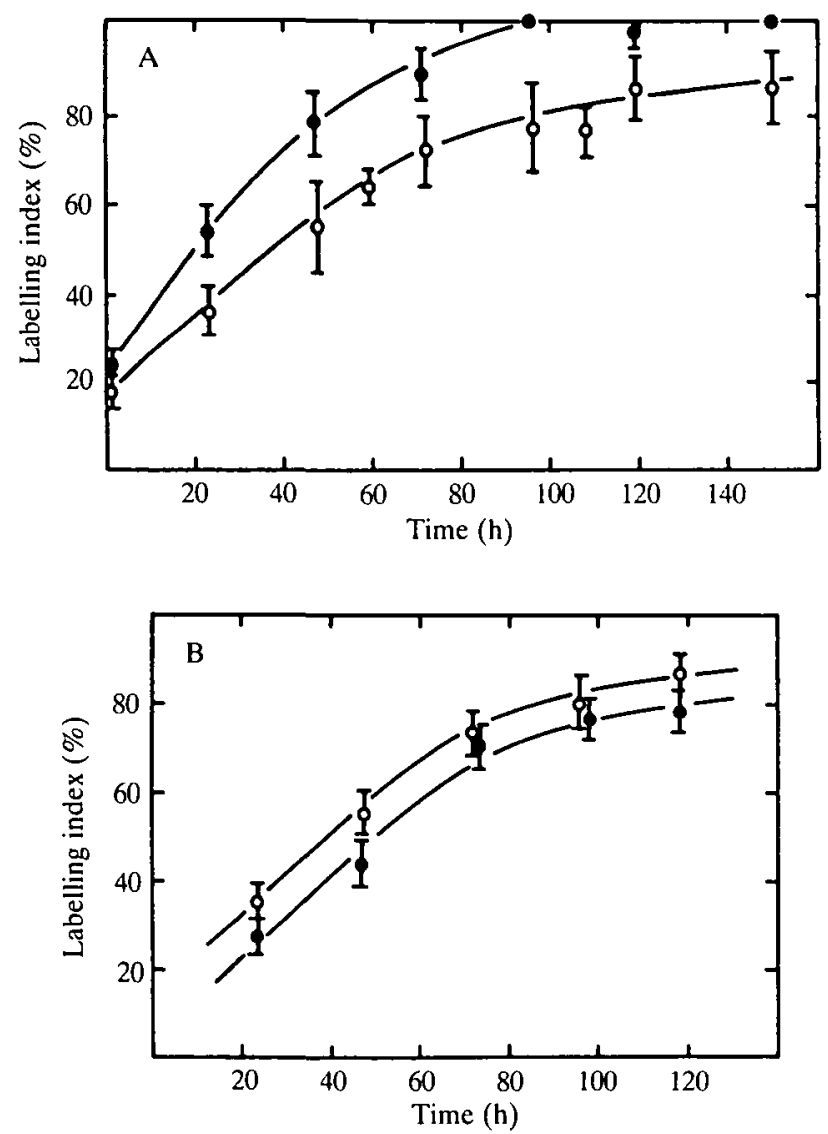

Fig. 1. Labelling index of gland cells in hydra continuously labelled with $\left[{ }^{3} \mathrm{H}\right]$ thymidine. Hydra were injected twice daily at 12 -h intervals with $25 \mu \mathrm{Ci}$ of $\left[{ }^{3} \mathrm{H}\right]$ thymidine and cultured as usual; 5 hydra were sampled for each time point; hydra to be sampled were labelled with $\left[{ }^{3} \mathrm{H}\right]$ thymidine for $1 \mathrm{~h}$ before preparing macerations. Averages and standard deviations from at least three experiments. A. Labelling index for the gastric region of hydra. Gland cells $(O)$ and epithelial cells $(\Theta)$. B. Gland cell labelling index for the upper half $(O)$ and lower half of the gastric region $(O)$ of hydra. 


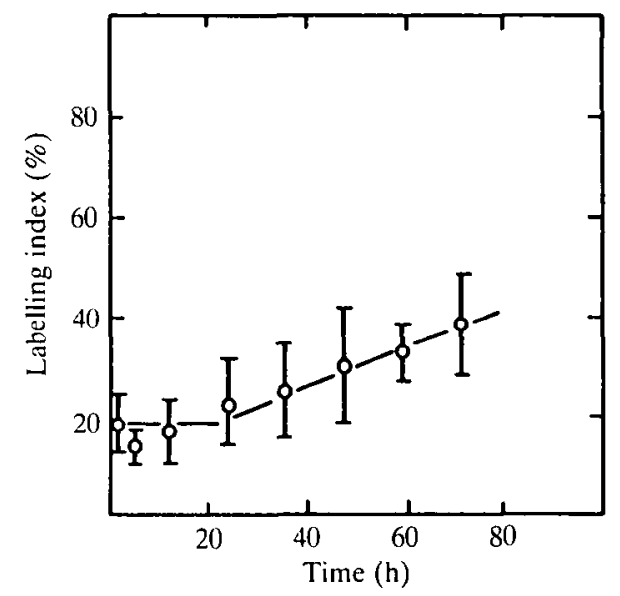

Fig. 2. Labelling index of gland cells in hydra pulse-labelled with $\left[{ }^{3} \mathrm{H}\right]$ thymidine. Hydra were injected once at the beginning of the experiment with $50 \mu \mathrm{Ci}$ of $\left[{ }^{3} \mathrm{H}\right]$ thymidine and cultured as usual. The gastric region of hydra was macerated for each time point. Averages and standard deviations from four independent experiments.

gastric region of Hydra. The fraction of $2 n$ cells increases further up the body column. In the subhypostomal region $2 n$ cells constitute about $27 \%$ of total gland cells while in the hypostome $>80 \%$ of the gland cells are $2 n$.

Fig. 4 shows the fraction of $2 n$ gland cells compared with the total number of gland cells in the different regions of Hydra. Owing to its distribution this subpopulation does not seem to be identical to the 'slow' population of gland cells, which is more pronounced in the lower body column of Hydra.

\section{The doubling time of gland cells}

Fig. 5 shows that the doubling time of the gland cell population in three independent experiments is about $83 \mathrm{~h}$ (calculated using linear regression). As expected this doubling time is comparable to the doubling time of epithelial cells (Fig. 5).

Table 1. Differentiation of gland cells from $\left[{ }^{3} \mathrm{H}\right]$ thymidine-labelled interstitial cells

\begin{tabular}{cccccc}
\hline \multirow{2}{*}{$\begin{array}{l}\text { Days } \\
\text { after } \\
\text { grafting }\end{array}$} & \multicolumn{2}{c}{ Gland cells } & & \multicolumn{2}{c}{ SEC 1 cells } \\
\cline { 2 - 3 } & Unlabelled & Labelled & & Unlabelled & Labelled \\
\hline 2 & 410 & 0 & & 65 & 0 \\
3 & 423 & 7 & & 58 & 0 \\
4 & 394 & 12 & & 63 & 0
\end{tabular}

$\left[{ }^{3} \mathrm{H}\right]$ thymidine labelled proximal halves were grafted to unlabelled distal halves. The table shows average number of labelled and unlabelled gland cells and SEC $1^{+}$cells in the distal third of grafted animals. Such pieces contain an average of 475 gland cells and 2350 interstitial cells. The labelling index of interstitial cells in the distal half at day 2 was $23 \%$, in the proximal half $83 \%$. At least four animals were analysed individually on each day. 

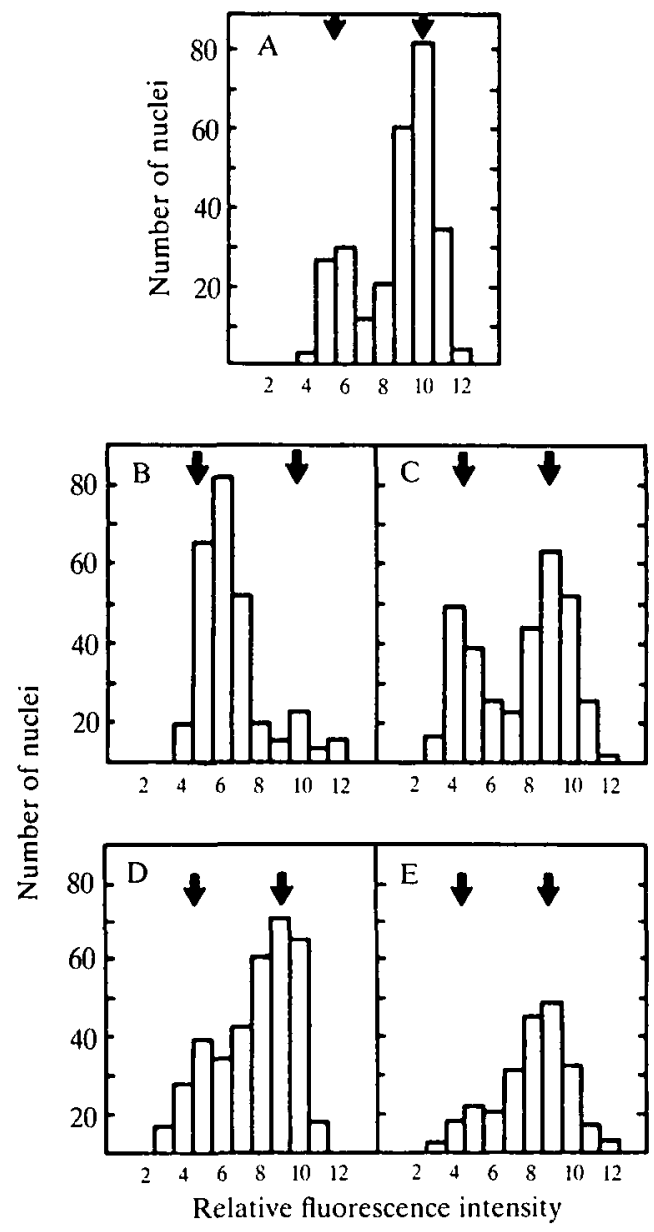

Fig. 3. Nuclear DNA content of gland cells as determined by microfluorometric measurements on single nuclei using the DNA-specific dye DAPI. Nuclei of nerve cells $(2 n)$ were used as reference to determine the position of $G_{1}$ and $G_{2}$ (arrows). Data are expressed as relative fluorescence intensities (arbitrary units). Gland cells in: $A$, the gastric region; $\mathrm{B}$, the head region; $\mathrm{C}$, the upper third, D, middle third, and $\mathrm{E}$, lower third of the gastric region of hydra.

\section{Continuous labelling of $\mathrm{G}_{1}$ and $\mathrm{G}_{2}$ gland cells}

In order to estimate the turnover times of the $G_{1}$ and $G_{2}$ populations, nuclear DNA measurements were done in conjunction with continuous labelling by $\left[{ }^{3} \mathrm{H}\right]-$ thymidine. For these experiments macerates of continuously labelled animals were first stained with DAPI and the DNA content of. individual gland cell nuclei was determined. Each measured cell was mapped on the microscope slide and, after subsequent autoradiography, scored for $\left[{ }^{3} \mathrm{H}\right]$ thymidine incorporation. Fig. 6A shows that labelled cells appear first in the $G_{2}$ population and increase rapidly until about $60 \mathrm{~h}$ after the onset of $\left[{ }^{3} \mathrm{H}\right]$ thymidine administration. The remaining $30 \%$ of the $G_{2}$ population is labelled more slowly in agreement with the labelling data from Fig. 1A. 
The first labelled $G_{1}$ cells appear about 50 to $60 \mathrm{~h}$ after the onset of $\left[{ }^{3} \mathrm{H}\right]$ thymidine labelling. The fact that $G_{1}$ cells begin to appear at about the same time at which the rate of labelling of $G_{2}$ cells decreases (Fig. 6A) suggests that these cells arise from $G_{2}$ cells. Thus $G_{2}$ and mitosis appear to take at least $50 \mathrm{~h}$.

The upper and lower gastric regions were also investigated separately to identify regional differences in the turnover of $G_{2}$ cells (Fig. 6B). Although the rate of labelling of $G_{2}$ cells was similar in both pieces up to $40 \mathrm{~h}$, the rate dropped thereafter to different extents in the different regions. $G_{2}$ cells in the upper gastric region were completely labelled within 3 days; cells in the lower gastric region were labelled

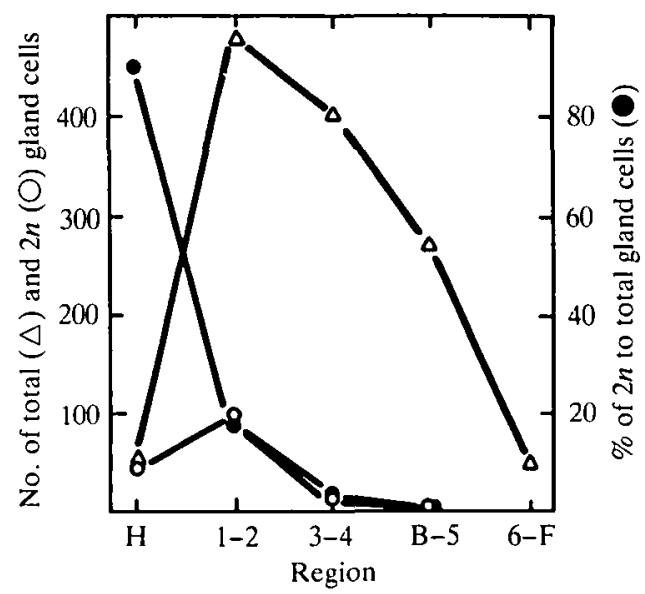

Fig. 4. The distribution of gland cells in Hydra. The total gland cell number was determined using macerates of the defined regions. After determination of the fraction of cells in the different phases of the cell cycle by microfluorometry the number of $G_{1}$ gland cells, as well as the fraction of $G_{1}$ gland cells, was calculated for the different regions.

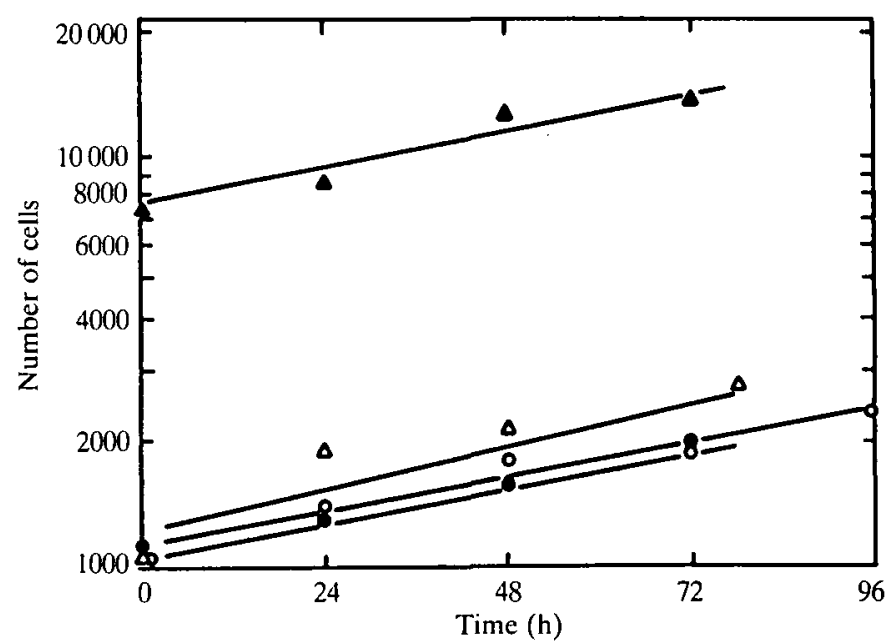

Fig. 5. The doubling time of gland cells compared with that of epithelial cells. Increase in gland cell number in three independent experiments $(\triangle, O, O)$ and epithelial cell number in one experiment $(\boldsymbol{\Delta})$. 
much more slowly. Thus the $G_{2}$ population, which turns over slowly, resides in the lower gastric region.

$G_{1}$ cells were labelled at the same rate and to the same extent in the upper as compared to the whole gastric region (data not shown). Since $G_{1}$ cells are scarce in the lower body region reliable data could not be obtained for this region.

\section{Evidence for differentiation from interstitial cells to gland cells}

To investigate whether gland cells can arise by differentiation of interstitial cells, labelled interstitial cells were introduced into unlabelled tissue by grafting. Proximal
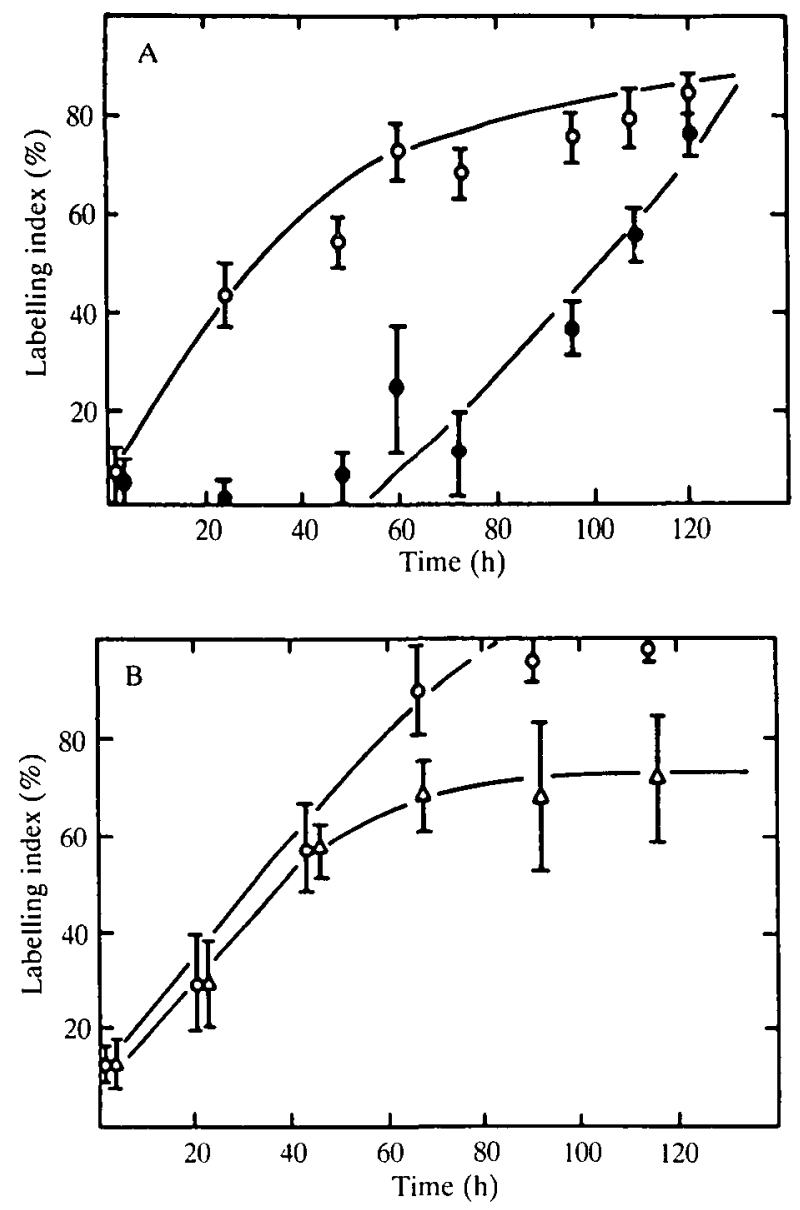

Fig. 6. Labelling index of $G_{1}$ and $G_{2}$ gland cells in hydra continuousiy labelled with $\left[{ }^{3} \mathrm{H}\right]$ thymidine. Hydra were injected twice daily at $12-\mathrm{h}$ intervals with $25 \mu \mathrm{Ci}$ of $\left[{ }^{3} \mathrm{H}\right]$ thymidine during the experiment and cultured as usual. Five hydra were sampled for each time point; hydra to be sampled were labelled $1 \mathrm{~h}$ before preparing macerations. Determination of nuclear DNA content in conjunction with autoradiography as described in Materials and Methods. Averages and standard deviations from three independent experiments. A. Labelling indices of $G_{1}(\Theta)$ and $G_{2}(O)$ gland cells from the gastric region of Hydra. B. Labelling indices of $G_{2}$ gland cells in the upper $(O)$ as well as lower gastric region $(\triangle)$ of Hydra. 
halves of $\left[{ }^{3} \mathrm{H}\right]$ thymidine-labelled hydra were grafted to unlabelled distal halves. In such grafts interstitial cells actively migrate into the unlabelled tissue (Tardent \& Morgenthaler, 1966; Heimfeld \& Bode, 1984). Grafts were incubated for 2-4 days, after which the distal third was excised, macerated and analysed for labelled interstitial cells and labelled gland cells. The results are shown in Table 1. After 2 days, about $25 \%$ of the interstitial cell population is labelled due to migration of labelled cells from the proximal half. Essentially no labelled gland cells are present in the distal pieces after 2 days. However, the number of labelled gland cells increases markedly between 2 and 4 days in the distal pieces. This increase is not due to migration of labelled gland cells, since excision of the labelled proximal half does not affect the result. Rather the appearance of labelled gland cells appears to be the result of differentiation from labelled interstitial cells that migrated into the distal half. By day 4 distal pieces contain about 12 labelled gland cells. This corresponds to about $3 \%$ of the gland cell population. Since the precursor interstitial cell population is about $25 \%$ labelled on day 2 and the differentiation occurred over a period of 2 days, the rate of differentiation corresponds to about $6 \%$ of the gland cell population per day.

\section{Evidence for a subpopulation of gland cells in the upper gastric region}

In the course of screening cell-type-specific monoclonal antibodies to Hydra cells, we isolated an antibody (SEC 1) that stains a subset of the gland cells. Most stained gland cells are morphologically indistinguishable from gland cells (Fig. 7). However, some stained cells exhibit cytoplasmic inclusions that are similar to those in mucus cells. Since the monoclonal antibody also stains a subpopulation of mucus cells in the hypostome, it appears likely that these cells represent intermediates in a differentiation pathway from gland cells to mucus cells.

SEC 1-positive cells constitute about $10 \%$ of the total gland cell population. They are located exclusively in the upper gastric region and in the hypostome (Fig. 8) in a pattern that is remarkably similar to the distribution of $G_{1}$ gland cells (Fig. 3). To investigate whether SEC 1 cells are the same as $2 n$ gland cells, the nuclear DNA content of SEC 1 gland cells was determined. Fig. 9 indicates that about $70 \%$ of the SEC 1 gland cells have $2 n$ nuclear DNA content while the remaining $30 \%$ have $S$ phase and $G_{2}$ nuclear DNA levels. Although most SEC 1 gland cells have $2 n$ DNA content, these cells constitute only about $30 \%$ of all $G_{1}$ gland cells in the upper gastric region (Fig. 9).

The presence of some SEC 1 cells with $S$ phase and $G_{2}$ DNA contents suggests that a portion of the SEC 1 population is actively proliferating. This was confirmed by pulse-labelling with $\left[{ }^{3} \mathrm{H}\right]$ thymidine: about $10 \%$ of the SEC 1 population was labelled by a single thymidine pulse.

The presence of large numbers of $G_{1}$ cells in the SEC 1 population suggests that these cells might be differentiation products of interstitial cells. (Nerve cells and nematocytes, which are major differentiation products of interstitial cells, have $G_{1}$ DNA levels (David \& Gierer, 1974).) To test this possibility newly differentiated 

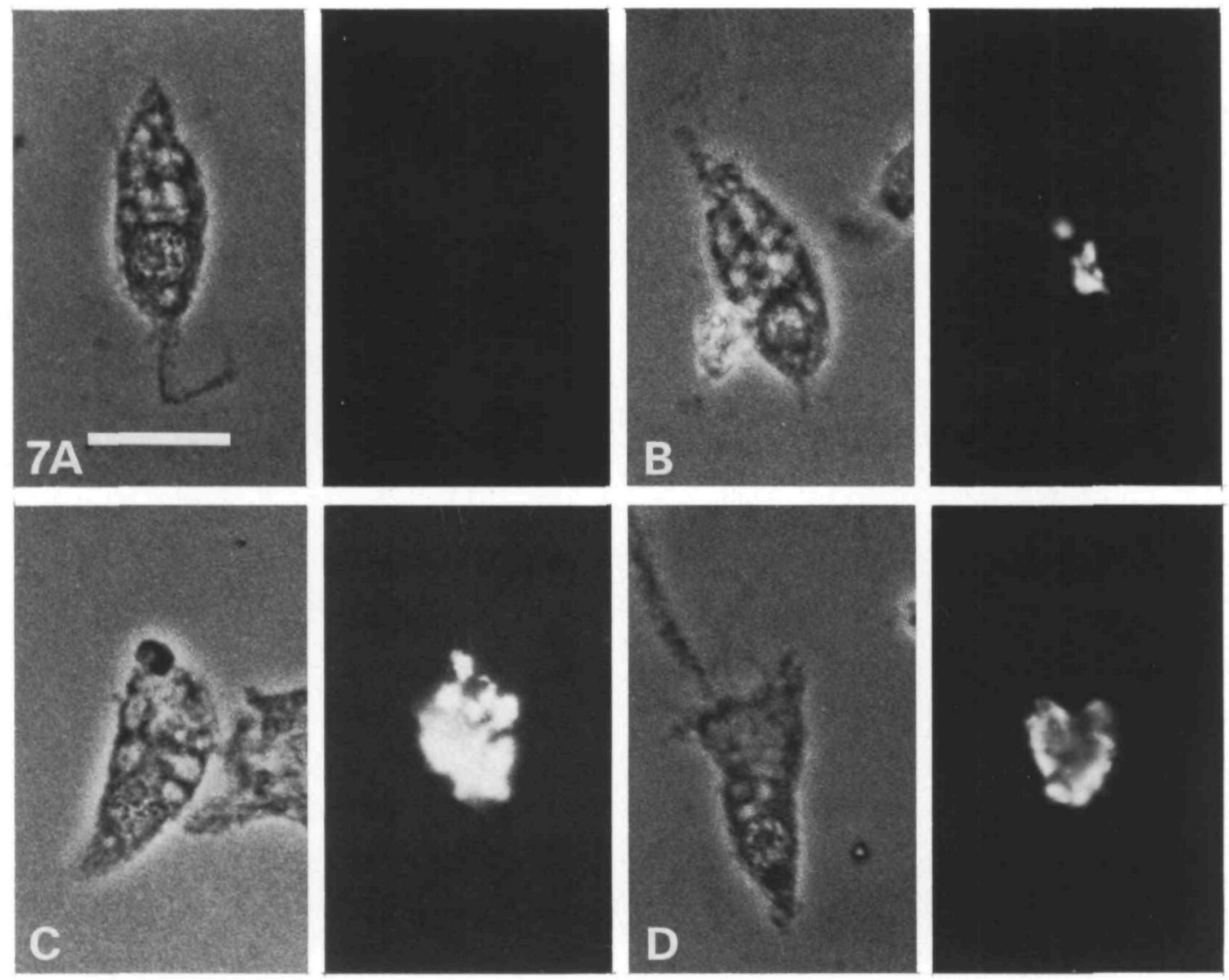

Fig. 7. Comparison of SEC $1^{+}$and SEC $1^{-}$gland cells. Phase-contrast micrographs of macerates with corresponding immunofluorescent image. A. Typical SEC $1^{-}$; and $\mathrm{B}, \mathrm{C}, \mathrm{SEC} 1^{+}$gland cells; D, SEC $1^{+}$gland/mucus cell intermediate. Bar, $25 \mu \mathrm{m}$.

gland cells were scored for SEC 1 antigen in the experiment shown in Table 1. No labelled SEC 1 cells were observed, indicating that these cells, unlike gland cells, do not arise from interstitial cells.

Further evidence that SEC 1 cells do not arise from interstitial cells was obtained in regeneration experiments with nitrogen-mustard-treated hydra. Nitrogen mustard treatment rapidly eliminates interstitial cells from hydra tissue (Diehl \& Burnett, 1964); such treatment does not inhibit regeneration. To investigate the role of interstitial cells in formation of SEC 1 cells, proximal halves of nitrogen-mustardtreated hydra were isolated and allowed to regenerate. Although such pieces do not contain SEC 1 cells at the onset of regeneration, SEC 1 cells are regenerated within 5 days (Fig. 8). Since interstitial cells are absent in nitrogen-mustard-treated tissue, the newly formed SEC 1 gland cells cannot arise from interstitial cells. In view of their morphological similarity to gland cells (Fig. 7), it appears more likely that SEC 1 cells arise from gland cells that are still present in nitrogen-mustard-treated tissue. 


\section{DISCUSSION}

\section{Characterization of gland cell populations}

On the basis of the results of continuous labelling experiments (Fig. 1A), gland cells consist of two kinds of cells: rapidly dividing cells, which are completely labelled by about $65 \mathrm{~h}$, and a second population, which is labelled much more slowly. This latter population is not homogeneous but rather consists of cells with $G_{1}$ and cells with $G_{2}$ DNA content (Fig. 6). These three populations and their interrelationships are shown schematically in Fig. 10.

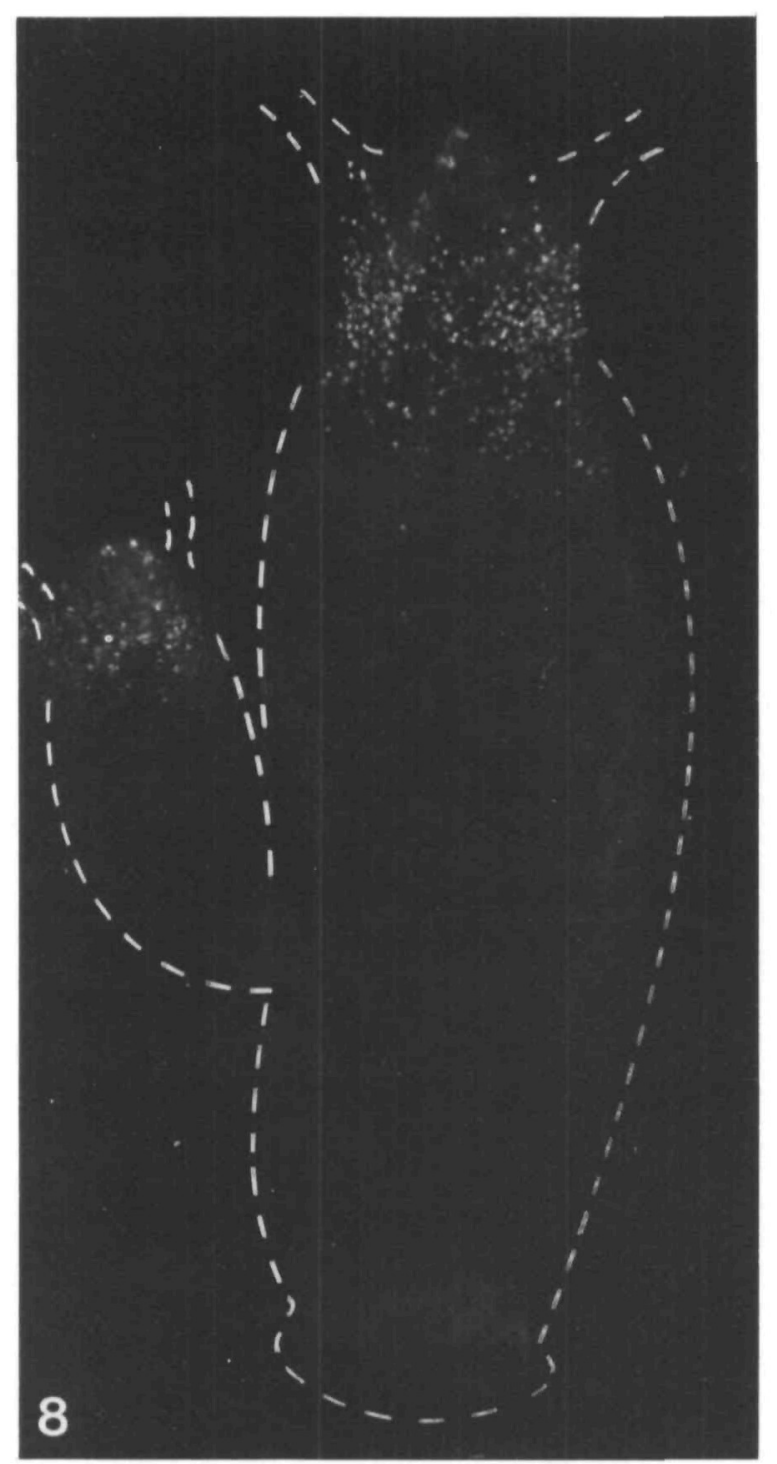

\section{Regeneration}

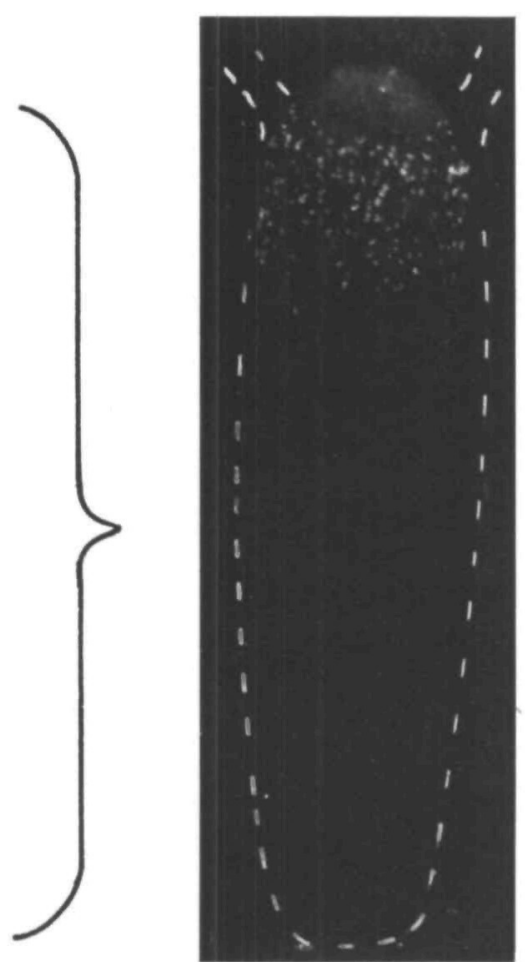

Fig. 8. Whole mounts of hydra stained with SEC 1 monoclonal antibody. Normal steady state animal (left) and nitrogen-mustard-treated regenerate (right). Bracket indicates region used for regeneration of distal structure. 


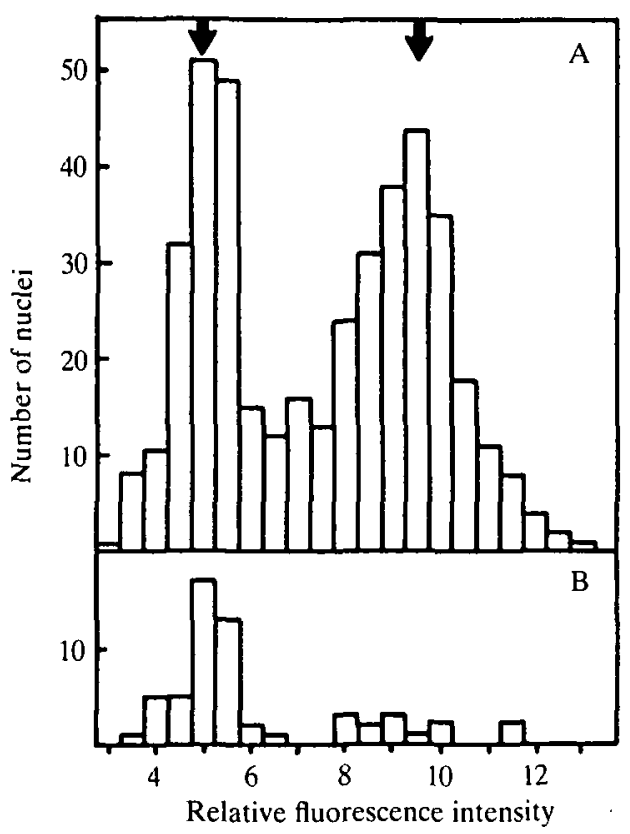

Fig. 9. Nuclear DNA content of total (A) and SEC $1^{+}$gland cells $(B)$ as determined by microfluorometric measurements on single cell nuclei using the DNA-specific dye DAPI. Nuclei of nerve cells $(2 n)$ were used as reference to determine the position of $G_{1}$ and $G_{2}$ (arrows). Data are expressed as relative fluorescence intensity (arbitrary units).

The rapidly labelled population comprises about $70 \%$ of all gland cells or about 650 cells per animal. It is completely labelled by about $65 \mathrm{~h}$. These cells are present in both the upper and lower gastric region (Figs 1B,6B) and appear to be cycling cells that are maintaining the gland cell population.

The slowly labelled population in Fig. 1 is not homogeneous but consists of two kinds of cells: $G_{1}$ cells and $G_{2}$ cells. $G_{1}$ cells are located in the upper gastric region and constitute about $15 \%$ of total gland cells or 190 cells (Fig. 3). They are labelled between 50 and $140 \mathrm{~h}$ under conditions of continuous labelling with $\left[{ }^{3} \mathrm{H}\right]$ thymidine (Fig. 6A). Because $G_{1}$ cells first become labelled at about the time the rapidly proliferating population is completely labelled, it appears that they arise from this population.

Direct evidence that $G_{1}$ cells are not part of the proliferating population can be deduced from the continuous labelling results in Fig. 6A. These results indicate that the turnover of $G_{2}$ gland cells is 2 days; for $G_{1}$ gland cells approximately 4 days. If $G_{1}$ is part of the cell cycle, then there must be twice as many more $G_{1}$ than $G_{2}$ cells. DNA measurements presented in Fig. 3 show that this clearly is not the case. Hence, as shown in Fig. 10, $G_{1}$ is an independent population of non-dividing cells, which arise from proliferating cells and turn over slowly. As shown below, about $30 \%$ of these cells exhibit a new antigen (SEC 1), which also distinguishes them from the population of proliferating gland cells.

$G_{2}$ cells that are part of the slowly labelled population are localized in the lower gastric region (Fig. 6B). There appear to be about 190 such cells since the total size 


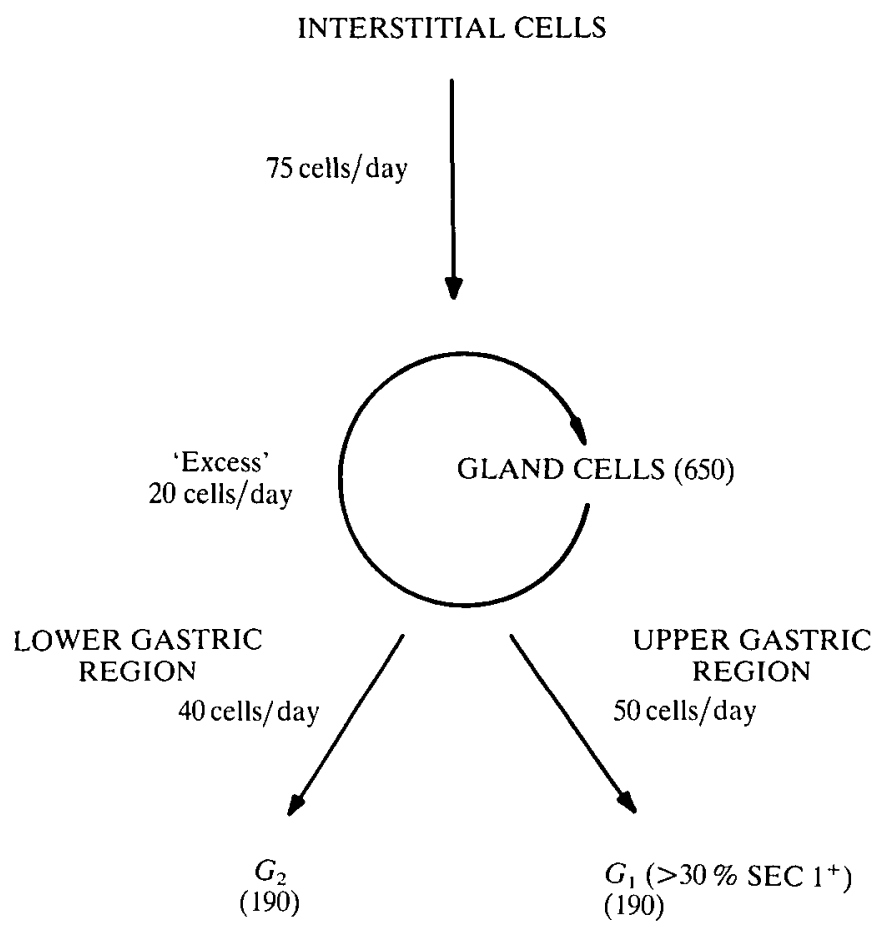

Fig. 10. Flowchart of gland cell populations. Numbers in parentheses indicate size of populations. 'Excess' means gland cells produced over and above growth requirements.

of the slow population is 380 cells and the $G_{1}$ cells constitute about 190 of these cells. This population becomes labelled between 3 and about 8 days under condition of continuous labelling. It appears to consist of cells that have exited from the proliferating population (Fig. 10). Possibly these cells are actively removed from the tissue, although it appears more likely that they are simply diluted out by continuing tissue growth.

\section{Duration of the gland cell cycle}

The continuous labelling experiments (Fig. 1) indicate that about $70 \%$ of the gland cell population is rapidly proliferating. Since the $G_{1}$ population observed in the DNA profile (Fig. 3) does not participate in the cell cycle, the gland cell cycle consists of $S, G_{2}$ and $M$ only, and thus is similar to that of other proliferating cell types in Hydra (David \& Campbell, 1972; Campbell \& David, 1974). The minimum duration of $G_{2}$ and $M$ can be estimated from Fig. $6 \mathrm{~A}$ as the time to the first appearance of labelled $G_{1}$ cells, i.e. $50 \mathrm{~h}$. The maximum $G_{2}$ duration can be estimated as the time at which the rapidly proliferating population is completely labelled (about $65 \mathrm{~h} ;$ Figs 1, 6A). Thus the duration of $G_{2}$ appears to vary significantly as it does for other proliferating cell types in Hydra.

The duration of the $S$ phase can be estimated from the pulse-labelling index, which is $17 \%$ of the total gland cells. Since only $70 \%$ of total cells are actively cycling (see 
above), the pulse-labelling index must be corrected for these non-cycling cells. The corrected labelling index is $17 / 70=24 \%$. Taking into account the age distribution of cycling cells (Bosch \& David, 1984), this results in an $S$ phase of about $14 \mathrm{~h}$, which is quite similar to estimates of $S$ phase for epithelial cells (David \& Campbell, 1972).

From the values for $G_{2}, M$ and $S$ phase, the cell cycle for proliferating gland cells can be calculated. The average cell cycle time is $72-74 \mathrm{~h}$, while the fastest cells in the population only take about $64 \mathrm{~h}$. These values are significantly shorter than the $83 \mathrm{~h}$ doubling time of the gland cell population (Fig. 5). Hence, gland cells appear to proliferate more rapidly than simple population growth requires. These 'excess' cells presumably contribute to the production of the non-cycling $G_{1}$ and $G_{2}$ gland cell populations.

\section{Maintenance of the gland cell population by proliferation and differentiation}

Maintenance of the gland cell population requires proliferation of the cycling cells sufficient to match population growth (doubling time $83 \mathrm{~h} ; \mathrm{Fig}$. 5) and to replace the non-cycling $G_{1}$ and $G_{2}$ gland cell populations. Turnover of the $G_{1}$ population (190 cells; Fig. 10) occurs in 4 days and thus requires an input of about 50 cells per day. Turnover of the $G_{2}$ population (190 cells; Fig. 10) occurs in about 5 days and thus requires an input of about 40 cells per day. Hence maintenance of the total gland cell population requires about 90 cells per day over and above the requirements of population growth.

As discussed above, the proliferative fraction of the gland cell population divides rapidly enough to match tissue growth and produces an excess of about $10 \%$ or 65 cells per cell generation, or about 20 cells per day. This excess production is, however, significantly smaller than the level of 90 cells per day required to replace the $G_{1}$ and $G_{2}$ populations. Thus, the gland cell population appears unable to maintain itself without some further source of cells.

The results in Table 1 and Fig. 2 indicate that gland cells arise from interstitial cells at a rate of about $6 \%$ of the gland cell population per day. The result is in agreement with observations on $H$. magnipapillata showing that about $7 \%$ of the gland cell population is daily replenished from interstitial cells by differentiation (Fujisawa, personal communication). Although earlier experiments indicated no differentiation from interstitial cell to gland cell in $H$. attenuata (Smid \& Tardent, 1984) more recent experiments show, that in this species gland cell differentiation also occurs (Tardent, personal communication).

The rate of gland cell differentiation corresponds to about 75 new gland cells per day. Together with the small number of excess cells produced by gland cell proliferation, it appears that the input into the gland cell population is sufficient to match the daily 'output' of about 90 cells. Thus the gland cell population appears to be maintained by a combination of cell proliferation and cell differentiation from interstitial cells.

The cell flow scheme in Fig. 10 shows interstitial cells differentiating to the proliferating population of gland cells. This appears to be the most reasonable interpretation of the data. However, it should be noted that we have no direct 
evidence, except in the case of the SEC 1-positive cells (Table 1), to show that interstitial cells do not enter the population of $G_{1}$ or $G_{2}$ gland cells.

\section{The function of SEC 1 gland cells}

The discovery of a small subpopulation of gland cells bearing a new antigen (SEC 1) was unexpected since the gland cell population is quite homogeneous. The localization of this subpopulation in the same regions as $G_{1}$ cells suggested that the occurrence of $G_{1}$ cells might be associated with the occurrence of the SEC 1 antigen. This simple explanation is not true since only about $30 \%$ of $G_{1}$ cells bear the SEC 1 antigen (Fig. 9).

On the basis of their morphological similarity (Fig. 7), SEC 1 cells appear to arise from proliferating gland cells. They do not arise by differentiation from interstitial cells since no SEC 1 cells were labelled in the experiment shown in Table 1 nor was the differentiation of SEC 1 cells inhibited in interstitial cell-free tissue (Fig. 8). Despite this clear evidence for differentiation from gland cells, some SEC 1 cells are labelled by a $\left[{ }^{3} \mathrm{H}\right]$ thymidine pulse and are thus in the cell cycle. The simplest explanation of this observation is that gland cells differentiating SEC 1 cells initiate synthesis of the SEC 1 antigen during the final cell cycle prior to differentiation.

The excellent technical assistance of Frl. Karin Bauer is gratefully acknowledged. We also thank $\mathrm{Dr}$ T. Fujisawa for sharing unpublished results, as well as $\mathrm{Dr} \mathrm{T}$. Holstein for critically reading the manuscript and for help with the plates. This study was supported by the Deutsche Forschungsgemeinschaft (DFG).

\section{REFERENCES}

BEUTLER, R. (1924). Experimentelle Untersuchungen über die Verdauung bei Hydra. Z. vergl. Physiol. 1, 1-56.

Bode, H., Berking, S., David, C. N., Gierer, H., Schaller, H. \& Trenkner, E. (1973). Quantitative analysis of cell types during growth and morphogenesis in Hydra. Wilhelm Roux Arch. EntwMech. Org. 171, 269-285.

Bosch, T. C. G. \& DAvid, C. N. (1984). Growth regulation in hydra: Relationship between epithelial cell cycle and growth rate. Devl Biol. 104, 161-171.

Bouillon, J. (1966). Les cellules glandaires des hydroides et des hydromeduses. Cahiers de Biologie Marine, 7, 190-205.

BURNETT, A. L. (1959). Histophysiology of growth in Hydra. F. exp. Zool. 140, 281-342.

Burnert, A. L. (1961). The growth processes in hydra. Y. exp. Zool. 146, 21-84.

Burnet, A. L., Davis, L. E. \& Ruffing, F. E. (1966). A histological and ultrastructural study of germinal differentiation of interstitial cells arising from gland cells in Hydra viridis. $\mathcal{Y}$. Morph. $120,1-8$.

Campbell, R. D. (1965). Cell proliferation in Hydra: an autoradiographic approach. Science 148, 1231-1232.

Campbell, R. D. (1967a). Tissue dynamics of steady state growth in Hydra littoralis. I. Patterns of cell division. Devl Biol. 15, 487-502.

CampBell, R. D. (1967b). Tissue dynamics of steady state growth in Hydra littoralis. II. Patterns of tissue movement. $\mathcal{~ Y . ~ M o r p h . ~ 1 2 1 , ~ 1 9 - 2 8 . ~}$

Campbell, R. D. \& Bode, H. R. (1983). Terminology for morphology and cell types. In Hydra: Research Methods (ed. H. M. Lenhoff), pp. 5-14. New York: Plenum Press.

CAmpbell, R. D. \& David, C. N. (1974). Cell cycle kinetics and development of Hydra attenuata. II. Interstitial cells. $\mathcal{Y}$. Cell Sci. 16, 344-358. 
Coleman, A. W. \& Maguire, M. J. (1982). A microspectrofluorometric analysis of nuclear and chloroplast DNA in Volvox. Devl Biol. 94, 441-450.

CORFF, A. (1973). Organismal growth and the contribution of cell proliferation to net growth and maintenance of form. In Biology of Hydra (ed. A. Burnett), pp. 146-187. New York: Academic Press.

David, C. N. (1973). A quantitative method for maceration of Hydra tissue. Wilhelm Roux Arch. EntwMech. Org. 171, 259-268.

David, C. N. (1983). Cell cycle analysis of hydra cells. In Hydra: Research methods (ed. H. M. Lenhoff), pp. 117-119. New York: Plenum Press.

David, C. N. \& Campbell, R. D. (1972). Cell cycle kinetics and development of Hydra attenuata. I. Epithelial cells. Y. Cell Sci. 11, 557-568.

DAVid, C. N. \& Gierer, A. (1974). Cell cycle kinetics and development of Hydra attenuata. 11I. Nerve and nematocyte differentiation. J. Cell Sci. 16, 359-375.

DAvis, L. E. (1973). Ultrastructural changes during dedifferentiation and redifferentiation in the regenerating, isolated gastrodermis. In Biology of Hydra (ed. A. L. Burnett), pp. 171-219. New York: Academic Press.

DiEHL, F. A. \& BURNETT, A. L. (1964). The role of interstitial cells in the maintenance of $H y d r a$. 1. Specific destruction of interstitial cells in normal, asexual, non-budding animals. $\mathcal{F}$. exp. Zool. $155,253-260$.

FradKIN, M., KAKIS, H. \& CAMPBell, R. D. (1978). Effects of gamma-irradiation of Hydra: Elimination of interstitial cells from viable Hydra. Radiat. Res. 76, 187-197.

Galfre, G., Howe, S. C., Milstein, C., Butcher, G. W. \& Howard, J. C. (1977). Antibodies to major histocompatibility antigens produced by hybrid cell lines. Nature, Lond. 266, 550-552.

Gauthier, G. F. (1963). Cytological studies on the gastroderm of Hydra. F. exp. Zool. 152, 13-39.

Gierer, A., Berking, S., David, C. N., Flick, K., Hansmann, G., Schaller, H. C. \& TrenkNER, E. (1972). Regeneration of hydra from reaggregated cells. Nature, Lond. 239, 98-101.

HAYNES, J. \& BURNETT, A. L. (1963). Dedifferentiation and redifferentiation of cells in Hydra viridis. Science 142, 1481-1483.

HAYNES, J. F. \& Davis, L. E. (1969). The ultrastructure of the zymogen cells in Hydra viridis. Z. Zellforsch. mikrosc. Anat. 100, 316-324.

HeImfELd, S. \& BODE, H. (1984). Interstitial cell migration in $H$. attenuata: I. Quantitative description of cell movements. Devl Biol. 115, 1-9.

Hess, A. (1961). The fine structure of cells in hydra. In The Biology of Hydra and Some Other Coelenterates (ed. H. M. Lenhoff \& W. F. Loomis), pp. 1-50. Coral Gables, Fla: University of Miami Press.

Johnson, G. D. \& DeNogueira Aranjo, G. M. (1981). A simple method of reducing the fading of immunofluorescence during microscopy. F. immun. Meth. 43, 349-350.

KESSLER, M. I. (1975). The origin, maturation and fate of the secretory cells in the gastrodermis of the brown hydra. Ph.D. thesis, University of Maine, Orono.

LeEman, U. \& RUCH, F. (1982). Cytofluorometric determination of DNA base content in plant nuclei and chromosomes by the fluorochrome DAPI and Chromomycin A3. Expl Cell Res. 140, 275-282.

LENhofF, H. M. \& Brown, R. D. (1970). Massculture in Hydra: an improved method and its application to other aquatic invertebrates. Lab. Anim. 4, 139-154.

LENTZ, T. L. (1965). The fine structure of differentiating interstitial cells in Hydra. Z. Zellforsch. mikrosk. Anat. 67, 547-560.

Macklin, M. \& BuRnetT, A. L. (1966). Control of differentiation by calcium and sodium ions in Hydra pseudoligactis. Expl Cell Res. 44, 665-668.

Marcum, B. A. \& Campbell, R. D. (1978). Development of Hydra lacking nerve and interstitial cells. Y. Cell Sci. 29, 17-33.

McConnell, C. H. (1929). Experimental observations upon the endodral glands of Pelmatohydra oligactis. Biol. Bull. mar. Biol. Lab., Woods Hole 56, 341-346.

McConNell, C. H. (1931). A detailed study of the endoderm of Hydra. F. Morph. 52, 249-275. 
Oi, V. T. \& HERzenBerg, L. A. (1980). Immunoglobulin-producing hybrid cell lines. In Selected Methods in Cellular Immunology (ed. B. B. Mishell \& S. M. Shiigi), pp. 351-372. San Francisco: W. H. Freeman.

Rose, P. G. \& BuRnetT, A. L. (1968). An electron microscopic and histochemical study of the secretory cells in Hydra viridis. Wilhelm Roux Arch. EntwMech. Org. 161, 281-297.

RubiN, D. I. \& BoDE, H. (1982). The aberrant, a morphological mutant of $H$. attenuata, has altered inhibition properties. Devl Biol. 89, 316-331.

Semal-van Gansen, P. (1954). L'histologie de l'endoderme de l'hydre d'eau douce. Annls Soc. zool. malac. Belg. 85, 217-278.

Smid, I. \& TARDENT, P. (1984). Migration of interstitial cells from ectoderm to endoderm in Hydra attenuata Pall. (Cnidaria, Hydrozoa) and their subsequent differentiation. Devl Biol. 106, 469-477.

Sugryama, T. \& Fujisawa, T. (1977). Genetic analysis of developmental mechanisms in Hydra. I. Sexual reproduction of Hydra magnipapillata and isolation of mutants. Dev. Growth Differ. 19, 187-200.

Sugryama, T. \& Fujisawa, T. (1978). Genetic analysis of developmental mechanisms in Hydra. II. Isolation and characterization of an interstitial cell-deficient strain. F. Cell Sci. 29, 35-52

Tannreuther, G. W. (1909). Budding in Hydra. Biol. Bull. mar. Biol. Lab., Woods Hole. 16, 210-214.

Tardent, P. \& Morgenthaler, U. (1966). Autoradiographische Untersuchungen zum Problem der Zellwanderung in H. attenuata Pall. Revue suisse Zool. 73, 468-480.

von Strelin, G. B. (1929). Zur Frage über den morphologischen Bau und die Herkunft einiger Zellelemente von P. oligactis. Zool. Anz. 79, 273-285.

WeiJer, C. J., Duschl, G. \& David, C. N. (1984). A revision of the Dictyostelium discoideum cell cycle. Y. Cell Sci. 70, 111-131.

(Received 8 fanuary 1986 - Accepted, in revised form, 16 fune 1986) 
